\title{
Seropositivity and pattern of viral hepatitis in clinically suspected cases of hepatitis in Dhaka city
}

\author{
Md. Tahminur Rahman ${ }^{1}$, Rosy Sultana ${ }^{1}$ and Sohel Reza Chowdhury ${ }^{2}$ \\ ${ }^{1}$ Department of Pathology and Immunology, Bangladesh Institute of Health Science, \\ Mirpur, Dhaka, Bangladesh; ${ }^{2}$ Department of Epidemiology and Research, National Heart Foundation, \\ Mirpur, Dhaka, Bangladesh.
}

\begin{abstract}
An attempt was made to see the seropositivity and pattern of four common hepatotrophic viruses (HBV, HCV, HEV, HAV) in patients suspected to have been suffering from viral hepatitis. Blood samples from 2,995 cases of suspected HBV infection, 331 from HCV, 155 from HEV and 24 from HAV were tested for these viral markers. Of these a total of 245 (8.1\%) were positive for HBsAg, 18 (5.4\%) for HCV, 87 (56.1\%) for HEV and 8 (33.3\%) were positive for HAV infection. The predominant age group affected in HBV is 25-40 years, for HCV >61 years, HEV 26-50 years and HAV under 11 years. Seropositivity for HBsAg was statistically higher (near double) in males than females $(p<0.05)$. HCV showed more seropositivity in males than females. HEV showed slight male preponderance and for HAV the female showed preponderance. The seropositivity rate was higher in Bangladesh in comparison to other developed and developing countries.
\end{abstract}

\section{Introduction}

Viral hepatitis a major public health problem globally, Bangladesh is no exception. The hepatotropic viruses are the most important cause of viral hepatitis and can cause hepatocellular injury ranging from subclinical inflammation to hepatic failure, cirrhosis, cancer and death apart from other causes like excessive alcohol consumption, use of certain hepatotoxic drugs and other types of infectious and nutritional agents. Among the most important hepatotrophic viruses, hepatitis B virus (HBV), hepatitis C virus (HCV), hepatitis A virus (HAV) and hepatitis $\mathrm{E}$ virus (HEV) are commonly prevalent in the world and also in Bangladesh. Overall HAV accounts for $25 \%$ of clinically evident acute hepatitis worldwide, HBV has infected over 2 billion people worldwide with a carrier of 350 million $^{1-3}$. HEV accounts for about $50 \%$ of cases of sporadic acute hepatitis in India and epidemics have also been reported in Indian subcontinent, sub-Saharan Africa and Mexico $^{4-6}$. The global prevalence varies from high $>8 \%$ in Africa, Asia, Western Pacific region, intermediate $2-7 \%$ in South Eastern Europe and low $<2.5$ in Western Europe, North America and Australia. Prevalence of HCV is $1.8 \%$ in general population in USA, increasing up to $50 \%$ in unexplained cirrhosis and hepatocellular carcinoma (HCC) and is the most common cause of chronic liver disease ${ }^{4-6}$.

The exact prevalence of hepatitis viruses varies from country to country and no exact data is available in Bangladesh. However some isolated studies on general population showed prevalence of $8.0 \%$ and different subpopulation like heterosexuals with multiple partners the prevalence was high $19.0 \% \%^{7-9}$. As the exact prevalence of hepatitis viruses are not known in Bangladesh, the present study was undertaken to determine the seropositivity of HBV, HCV, HEV, HAV in patients suspected clinically of having these infections. This will throw some light on the seropositivity of various types of hepatitis in Bangladesh and will try to help to define better preventive and curative measures.

\section{Materials and Methods}

Between March 2003 to September 2005 a total of 2995 patients suspected to have been suffering from HBV infection, 331 cases of suspected HCV, 156 cases of suspected HEV and 24 cases of suspected HAV infection based on clinical examination and history seen by clinicians at 
different centers of Bangladesh Institute of Health Science at Dhaka were included in this study. Clinically suspected patient means the patients have clinical symptoms like anorexia, nausea, vomiting, diarrhea, itching, yellow discoloration of skin and mucous membrane, high colored urine, pale stool, past history of blood transfusion, unsafe sex, sharing of needles, razors etc. In all these patients $5 \mathrm{ml}$ of blood were taken aseptically and sent to Immunology department of Bangladesh Institute of Health Sciences central laboratory at Mirpur for testing. Sera were subjected to Enzyme Linked Immunoabsorbant Assay (ELISA). HBsAg, anti-HAV IgM were assessed using commercially available ELISA kits from Diasorin, Italy, antiHCV IgM antibodies were detected by kits from MBS (Medical Biological Services, Italy). Positive samples of HBsAg, anti-HCV, anti-HEV, antiHAV were reconfirmed by repeat ELISA (Organon Tecknica, Netherlands).

\section{Results}

A total of 245 (8.1\%) out of 2,995 cases of suspected $\mathrm{HBV}$ infection were found positive for HBsAg. The seropositivity was higher in males $n=167$ (68.2\%), almost double than females $n=78$ $(31.8 \%)$ which was statistically significant $(\mathrm{p}<0.05)$. Most of the positive cases were between $25-40$ years of age group. The mean age \pm SE of the patient was $39.3 \pm 0.2$ years.

Among the total 331 cases of suspected HCV and tested for anti-HCV IgM 18 (5.4\%) came out as positive. The seropositivity is higher in males $n=10$ (55.5\%) than females $n=8 \quad(45.5 \%)$. The predominant positive age group was $40-70$ years $\mathrm{n}=17$ (94.4\%), $\mathrm{n}=1$ (5.6\%) was under 40 years.

Among 155 suspected cases of HEV infection 87 (56.1\%) showed seropositivity. The predominant age group of positive cases was $26-50$ years $n=43$ (49.4\%), 23 belong to age group 51-70 years $n=23$ (26.4\%) with slight male preponderance, male $\mathrm{n}=46(52.9 \%)$ and female $\mathrm{n}=41(47.1 \%)$. The mean age \pm SE of the patient was $38.2 \pm 1.3$ years.

Out of total suspected cases of HAV infection, $n=8$ (33.3\%) were anti-HAV IgM positive. 6 (75\%) were under 17 years of age and a slight female preponderance was seen in HAV seropositive cases, female $n=5$ (62.5\%) and male $n=3$ (37.5\%). Seropositivity for anti-HAV, HEV IgM indicates suggestive of recent infection. Moreover we noticed an increase of $\mathrm{HEV}$ infection in rainy season (June to August) data not shown. Cumulative results are shown in Table I and II.
Table I: Status of hepatitis patients grouping of age cross distribution

\begin{tabular}{|c|c|c|c|c|c|}
\hline \multirow{2}{*}{$\begin{array}{l}\text { Status of } \\
\text { hepatitis } \\
\text { patients }\end{array}$} & \multicolumn{4}{|c|}{ Grouping of age total } & \multirow[t]{2}{*}{ Total } \\
\hline & $\begin{array}{r}0-25 \\
\text { years }\end{array}$ & $\begin{array}{r}26-50 \\
\text { years }\end{array}$ & $\begin{array}{r}51-75 \\
\text { years }\end{array}$ & $\begin{array}{r}>75 \\
\text { years }\end{array}$ & \\
\hline HBsAg -ve & 525 & 1601 & 601 & 23 & 2750 \\
\hline HBsAg +ve & 53 & 142 & 46 & 4 & 245 \\
\hline HAV -ve & 4 & 7 & 5 & 0 & 16 \\
\hline HAV +ve & 6 & 2 & 0 & 0 & 8 \\
\hline HCV -ve & 28 & 184 & 99 & 2 & 313 \\
\hline $\mathrm{HCV}+\mathrm{ve}$ & 1 & 9 & 8 & 0 & 18 \\
\hline HEV -ve & 20 & 32 & 15 & 1 & 68 \\
\hline $\mathrm{HEV}$ +ve & 21 & 23 & 43 & 0 & 87 \\
\hline Total & 658 & 2000 & 817 & 30 & 3505 \\
\hline
\end{tabular}

Table II: Status of hepatitis pattern sex of the patient cross tabulation

\begin{tabular}{|c|c|c|c|}
\hline \multirow{2}{*}{$\begin{array}{l}\text { Status of hepatitis } \\
\text { patients }\end{array}$} & \multicolumn{2}{|c|}{ Sex of the patient } & \multirow[t]{2}{*}{ Total } \\
\hline & Male & Female & \\
\hline HBsAg -ve & 1322 & 1428 & 2750 \\
\hline HBsAg +ve & 167 & 78 & 245 \\
\hline HAV-ve & 8 & 8 & 16 \\
\hline HAV +ve & 3 & 5 & 8 \\
\hline HCV -ve & 193 & 120 & 313 \\
\hline $\mathrm{HCV}+\mathrm{ve}$ & 10 & 8 & 18 \\
\hline HEV-ve & 38 & 30 & 68 \\
\hline $\mathrm{HEV}+\mathrm{ve}$ & 46 & 41 & 87 \\
\hline Total & 1787 & 1718 & 3505 \\
\hline
\end{tabular}

\section{Discussion}

The present study indicates a higher seropositivity of HAV, HEV, HBV, HCV in patients suspected of suffering from viral hepatitis due to these hepatotrophic viruses in Bangladesh. It does not reflect the exact prevalence of hepatotrophic viral hepatitis in Bangladesh but this probably reflects the current situation related to viral hepatitis in Bangladesh. The seropositivity of HAV and HEV are quite high and alarming in Bangladesh as evident from this study. It is well known that these two viruses cause infections in crowded residential areas and spread by feco-oral route. One important issue as evident from this study is very high seropositivity of HAV (75\%) infection in young adults predominantly under 17 years of age. This indicates that HAV infection is acquired in early years of life. The younger population takes food and drinks from different fast food restaurants, 
open hotels, restaurants in crowded, slum areas where the hygiene is not properly maintained. Also surface water of rivers and lake may be contaminated with HAV and may act as a source of HAV infection ${ }^{10}$. This is corroborative with other studies in India and Pakistan where they found that about $60 \%$ and $85 \%$ children acquired HAV infection mainly through sub clinical infection.

The higher seropositivity of HEV infection among adults (56.1\%) compared to children and young adults is also similar to that of research work published on population based studies and in India $^{11}$, Pakistan ${ }^{9}$, Hong Kong ${ }^{12}$ and Somalia ${ }^{10}$. It is not well known why this infection is common in adults, however one probable explanation is that the adults consumes more food, exposed to different food and drinks in comparison to children. This leads the adults more vulnerable to this infection through contaminated food and water. Added factors may include rainy season, flood, contaminated water supply but extensive studies are needed involving larger population from different geographical areas from different countries to establish these factors.

Although hepatitis B vaccine is available 25 years back still majority of the population of Bangladesh can not afford to buy this vaccine and take it because of its high price. More over unsafe use of blood and blood products, sharing of needles, unsafe sex and lack of proper knowledge regarding hepatitis B is prevailing in Bangladesh. This is well reflected by the high seropositivity of $\mathrm{HBsAg}$ (8.1\%) in suspected cases of HBV infection. There is statistical significant difference in $\mathrm{HBsAg}$ seropositivity between male and female $(\mathrm{p}<0.05)$. Also the mean age of HBsAg patients is 39.7 years which reflects the active part of life and suffering from this dreadly disease means reduced activity, more economic and social burden for the patient and his family. Our seropositivity is less than that of Pakistan ${ }^{9}$ and Kenya ${ }^{13}$ where the seropositivity found is $10 \%$ and $26.2 \%$ respectively. The prevalence is also higher in Italy where the prevalence of HBsAg is $13.4 \%^{14}$.

HCV transmits via unscreened blood, shared needles, hemodialysis and unsafe sex. These are also same for Bangladesh and the HCV seropositivity in the present study is $5.4 \%$. The mean age of the seropositive cases is 44.9 years also indicating active part of life and like HBV it is also true that this positivity will create reduction in activity, induce economic and social burden for the patient and his family. This seropositivity for HCV is less than that of Pakistan ${ }^{9}$, Kenya ${ }^{13}$, Thialnd ${ }^{15}$ and same in Italy ${ }^{14}$ where the prevalence of HCV is
$6 \%, 7.1 \%, 7.8 \%$ and $5.7 \%$ respectively. This difference may be due to small sample number, not done in general population. Another survey in a small Mediterranean town ${ }^{16}$ showed the prevalence of $\mathrm{HCV}$ is $4.5 \%$ high in individuals over the age of 50. This is consistent with the present study where the mean age is around 45 years.

In conclusion, the present study indicates high seropositivity of hepatotropic viruses like HAV (33.3\%), HEV (55.7\%), HBV (8.1\%), HCV (5.4\%) in patients suspected to have suffering from hepatitis in Bangladesh. Seropositivity of HBV and HCV were more in the active period of life (the mean age of 39.7 years and 44.9 years respectively) and HBV positivity was significantly higher in females than males. Urgent and strict preventive measures mentioned are needed to combat this menace.

\section{Acknowledgement}

The authors wish to thank and express gratitude to the Bangladesh Institute of Health Sciences authority for giving permission to utilize the data of suspected cases used in this paper.

\section{Authors contribution}

MTR: Preparation of the manuscript

RS: Performing the hepatitis panel tests

SRC: Compilation and analysis of data

\section{References}

1. Mohler-Kuo M, Steffen R, Bopp M, Jacobs RJ, Mutsch $\mathrm{M}$. Prevalence of hepatitis A virus risk factors in a very low endemic country, Switzerland. Vaccine 2007; 25: 8718-25.

2. Minuk GY, Sun A, Sun DF, Uhanova J, Nicolle LE, Larke B, Giulivi A. Serological evidence of hepatitis E virus infection in an indigenous North American population. Can J Gastroenterol. 2007; 21: 439-45.

3. Bayram A, Eksi F, Mehli M, Sozen E. Prevalence of hepatitis $\mathrm{E}$ virus antibodies in patients with chronic hepatitis B and chronic hepatitis C. Intervirology 2007; 50: 281-86.

4. Spada E, Abbate I, Sicurezza E, Mariano A, Parla V, Rinnone S, Cuccia M, Capobianchi MR, Mele A. Molecular epidemiology of a hepatitis $C$ virus outbreak in a hemodialysis unit in Italy. J Med Virol. 2008; 80: 216-17.

5. Nahar D, Biswas J, Nahar A, Haque KMG, Islam A, Mannan MA. Hepatitis B virus infections in patients with chronic liver disease. Bangladesh Med Assoc J. 2001; 30: 43-45.

6. Haque MM, Mamun SA, Khan RM, Hassan KM, Salam A. Hepatitis B virus infection in heterosexual 
men having multiple sex partners. Bangladesh Med Assoc J. 2004; 33: 78-85.

7. Khan WI, Sultana R, Rahman M, Akhter H, Haq JA, Ali L, Mohsin MA, Khan AKA. Viral hepatitis: Recent experiences from serological studies in Bangladesh. Asian Pacific J Allergy Immunol. 2000; 18: 99-103.

8. Shapiro CN, Mangolis HS. Worldwide epidemiology of hepatitis A virus infection. J Hepatol. 1993; 18 (Suppl 2): S11-14.

9. Mujeeb SA, Shaikh MA, Kehar SI. Prevalence of HB infection in hemodialysis patients. J Pak Med Assoc. 1994; 44: 226.

10. Mushawar IK, Dawson GJ, Bile KM, Magnius IO. Serological studies of an enterically transmitted non-A non-B hepatitis in Somalia. J Med Virol. 1993; 40: 218-21.

11. Arankalle VA, Tsarev SA, Chadha MS, Alling DW, Emerson SU, Banerjee K, Purcell RH. Age specific prevalence of antibodies to hepatitis A and $\mathrm{E}$ viruses in Pune, India, 1982 and 1992. J Infect Dis. 1995; 171: 447-50.

12. Lok AS, Kwan W, Moeckli, Yarbough PO, Chan RT, Reyes GR, Lai CL, Chung HT, Lai TST. Seroepidemiological survey of hepatitis E in Hong
Kong by recombinant-based enzyme immunoassays. Lancet 1992; 340: 1205-08.

13. Atina JO, Oguto EO, Hardison WG, Mumo J. Prevalence of hepatitis A, B, C and human immunodeficiency virus seropositivity among patients with acute icteric hepatitis at the Kenyan National Hospital. East Africa Med J. 2004; 81: 183-87.

14. Sagnelli E, Stroffolini T, Mele A, Almasio P, Coppola N, Ferrigno L, Scolastico C, Onofrio M, Imparoto M, Fillipini P. The importance of HCV on the burden of chronic liver disease in Italy: A multi-center prevalence study of 9997 cases. J Med Virol. 2005; 75: $522-27$.

15. Sungkanuparph S, Vibhagool A, Manosuthi W, Kiertiburanakul S, Atamasirikul K, Aumkhyan A, Thakkinstian A. Prevalence of hepatitis B virus and hepatitis $\mathrm{C}$ virus co-infection with human immunodeficiency virus in Thai patients: A tertiarycare-based study. J Med Assoc Thai. 2004; 87: 134954.

16. Pendino GM, Mariano A, Surace P, Caserta CA, Fiorillo MT, Amante A, Bruno S, Mangano C, Polito I, Amato F, Cotichini R, Stroffolini T, Mele A, ACE Collaborating Group. Prevalence and etiology of altered liver tests: A population based survey in a Mediterranean town. Hepatology 2005; 41: 1151-59. 